\title{
STUDENT ABSENTEEISM IN ENGINEERING COLLEGES: EVALUATION OF ALTERNATIVES USING AHP
}

\author{
P. KOUSALYA, V. RAVINDRANATH, AND K. VIZAYAKUMAR
}

Received 3 January 2006; Revised 29 August 2006; Accepted 24 September 2006

The present study illustrates the application of analytical hierarchy process (AHP) to a decision-making problem. AHP is a popular and powerful method for solving multiple criteria decision-making (MCDM) problems. An attempt is made here to initialize the use of multicriteria decision-making methods for ranking alternatives that curb student absenteeism. Through the expert opinions, the criteria that cause student absenteeism are identified and the criteria hierarchy was developed. The relative importance of those criteria for Indian environment is obtained through the opinion survey. Alternatives that curb student absenteeism in engineering colleges like counseling, infrastructure, making lecture more attractive, and so forth were collected from literature, journals' surveys and experts' opinions. Alternatives are evaluated based on the criteria, and the preferential weights and ranks are obtained. The experts' opinions are validated by Saaty's inconsistency test method. "Involvement of parents" is the best alternative given by the group of experts. Parents have to know their ward's day-to-day progress in college. The second best alternative is "counseling," as many criteria that cause student absenteeism are reduced by counseling.

Copyright (c) 2006 P. Kousalya et al. This is an open access article distributed under the Creative Commons Attribution License, which permits unrestricted use, distribution, and reproduction in any medium, provided the original work is properly cited.

\section{Introduction}

Our motivation for this research is to answer the following questions.

(1) Can a framework be established to provide a method for ranking of alternatives, which curb student absenteeism when multiple criteria are utilized?

(2) Can the criteria that most significantly contribute to the alternatives be identified?

Student absenteeism is always a concern in educational institutes as their learning is directly related to it. It attains more importance in colleges and institutions offering professional courses like engineering, medicine, and so forth. This concern is always discussed 
in academic circles, but scientific studies are very few. An attempt is made here to probe the issue in a scientific way and to obtain some common and generally applicable solutions.

This study is concentrated on the absenteeism of students in engineering colleges in the state of Andhra Pradesh in India. In this state, the intake of students in engineering courses has grown, in the last decade, about five times from 13000 to about 80000 every year as many engineering colleges are established in private sector.

Establishment of many engineering colleges has created a wide opportunity to many students to aspire to become engineers. Many parents thrust their children to become engineers without assessing or allowing them to choose between available courses, suitable to their interests and ability. Students have to appear for EAMCET (engineering agriculture medicine common entrance test), equivalent to SAT, to get admission into engineering, agricultural and medical colleges. Special coaching institutions which are interested in making quick money organize coaching classes in a residential mode and subject students to restless reading rather than studying and understanding the concepts.

An inexplicable tension, therefore, develops in students till such time they secure admission into engineering colleges. Students and parents view engineering education as a means of getting a job to make money and fail to understand the importance of knowledge and its application in building overall character and leadership skills. Once admission into an engineering college is secured, both the students and parents relax, as they think that obtaining the degree and a good job is assured.

Adolescence in its natural way makes one long for a carefree life in an atmosphere totally different and far away from the care and control of parents. Different courses and new college environment may sometimes make it difficult for the students to get acclimatized to the engineering curriculum. Students consequently fail to gain the right aptitude for engineering education. Absenteeism can be one convenient way out to escape from the systematic engineering curriculum. Neither the students have an interest to fit into the engineering system nor their parents check whether their wards are attending the classes or not. So there is a necessity to conduct a study, which will throw light on the causes of student absenteeism.

\section{Background}

A Survey conducted among the teachers of engineering colleges (Kousalya [12]) brought forth that the absenteeism of students is very high at an average of $30 \%$ overall and even $50 \%$ in some subjects. She found that the absenteeism is more in students with low EAMCET rank holders comparatively than in high-rank holders. However, she did not draw any conclusions on the causes of absenteeism and suggested a thorough scientific study. Department of education [3] found in a study that chronic student absenteeism is indicated by 21 or more absences for a student during the regular (180-day) school year. Because chronic absenteeism is often associated with academic underachievement and increased risk of dropping out of school, it is necessary to determine where and when highest incidents of chronic absenteeism occur. Students' socioeconomic status (as indicated by eligibility for free/reduced price lunch), their racial/ethnic classification, and 
their age/grade classification are variables that are useful in identifying key factors in absenteeism.

Pearce [14] studied the absenteeism characteristics of biology first-year students at the Institute of Science Education, University of Plymouth. His study indicated that most students agree that attendance at lectures and practical sessions affects their overall academic performance. The study showed that the most common reasons given for absence were the timing and content of lectures followed by illness or the after effects of alcohol or drugs. Issues such as social, domestic, and financial factors were found not to be important factors as far as attendance was concerned. The attendance data also indicated that lectures that were not mainstreaming biology modules were poorly attended.

A study by the National Center for Educational Statistics (1997) [13] presented that the principals in high schools were more likely to report tardiness, absenteeism/class cutting, and student drug use as serious or moderate problems in 1997 (67, 52, and 36 percent, resp.) than in 1991 (50, 39, and 20 percent, resp.).

US Department of Education, Office of Educational Research and Improvement [28] revealed that the student absenteeism and class cutting is about 52\% in USA.

Boloz and Lincoln [1] have studied absenteeism in schools and suggested involvement of parents and more frequent meetings with them by teachers. Skipping classes, particularly big lectures where an absence can go undetected, is a tradition among college undergraduates who party late or swap notes with friends.

Silverstein [25] expressed that these days professors are witnessing a spurt in absenteeism as an unintended consequence of adopting technologies originally envisioned as learning aids.

According to Garvin [7], "one of the fundamental problems is student absenteeism," which, he says, is a "traditional feature of second year at UCD."

Director of health services [4], in his study at the University of Pittsburgh, concluded that when a student is absent from class due to illness or injury, it is the responsibility of the student to communicate with his/her professor and to follow the requirements of the professor regarding the course work missed. Penalties for absenteeism depend upon the policy and discretion of the professor, as outlined in the course syllabus.

Timmins and Kaliszer [26] explored the views of those involved in nurse education in Ireland to absenteeism among diploma nursing students to ascertain whether or not concern exists. The findings reveal absenteeism as a potential problem among nursing students. Most respondents agree that student attendance at both the practical and theoretical aspects of current education programmes is a problem. There is overwhelming agreement that student attendances while on the clinical area should be monitored, while the majority of respondents agree that attendance monitoring during lectures should take place. Systematic policies need to be developed and enforced.

Gorman et al. [8] investigated perceived popularity and perceived teacher preference and obtained data on GPAs and unexplained absences. Multiple regression analyses revealed that low GPA, low submissiveness, and high rates of absenteeism were associated with high perceived popularity and a low perceived teacher preference.

Day et al. [2], have found that the teacher commitment has an important influence on students' motivation, achievement, attitudes towards learning, and absenteeism. 
The above literature reveals that the problem of student absenteeism is a multicriteria problem. Also, enough information is not available about the student attitudes of engineering colleges in India.

Saaty $[21,22]$ gave a method for measuring the relative importance of multiple criteria by structuring the functions of a system hierarchically. Saaty [24] introduced AHP, a multicriteria decision-making approach by giving the principles and philosophy of the theory. He used AHP for several cases, such as school selection, overall satisfaction with a job, and obtaining a relationship between the illumination received and of the distance from the source. Saaty [23] showed that, contrary to what Professor Dyer has laid, for rank reversal in relative measurement mode of the AHP for which there is no parallel in utility theory.

Yue et al. [27] in their paper introduced a convenient procedure for ranking $N$ alternatives through direct comparisons in AHP. The alternatives were divided into groups in such a way that dominant relationship exists between the groups but not among the alternatives within each group.

Reddy et al. [20] presented a method for performance evaluation of technical institutions by analytical hierarchy method. Dyer $[5,6]$ provided a brief review of several areas of operational difficulty with the AHP and then focused on the arbitrary rankings that occur when the principle of hierarchic composition is assumed. Harker $[9,10]$ presented an overview of the philosophy and methodology, which underlies the analytic hierarchical process by describing the method along with its mathematical underpinnings, and the AHP has demonstrated the robustness across a range of applications' domains, and discussed the central element, concerned with rank reversal. Phillips-Wren et al. [15] proposed a frame work to evaluate decision support systems (DSSs) that combines outcome and process oriented evaluation measures. Islam [11] developed certain techniques to extract the underlying weights from different types of pairwise comparison matrices in the framework of analytic hierarchy process. Ramanathan and Ganesh [19] proposed a simple and appealing eigenvector-based method to intrinsically determine the weightages for group members using their own subjective opinions and also its superiority over other methods.

Prabhu and VizayaKumar [18] illustrated the use of fuzzy hierarchical decisionmaking (FHDM) for steel-making technology considering the Indian conditions. Ramsha Prabhu and VizayaKumar [17] presented the use of fuzzy hierarchical decision-making (FHDM) for the selection of an appropriate technology. Prabhu [16] identified various criteria for technology evaluation, suggested suitable framework and methodology for technology choice, and applied fuzzy MCDM for this.

\section{Methodology}

3.1. Problem definition. Student absenteeism in engineering colleges is found to be an important concern in producing quality engineers to the nation as it is found that the quality is directly proportional to absenteeism. The aims of the work are

(i) to identify the causes for student absenteeism in engineering colleges,

(ii) to identify alternate solutions to curb absenteeism, 
(iii) to evaluate the alternatives with the identified criteria in order to recommend the feasible and better solutions to the problem, and

(iv) to demonstrate the use of AHP in educational management.

A questionnaire survey and Delphi method are used to identify the causes of absenteeism, and alternate solutions to curb absenteeism. As the problem is found to involve, multicriteria decision-making, AHP is chosen to analyze the data.

In the literature of multicriteria decision-making (MCDM) analysis, there exist a large number of methods, such as simple weighted average method, elimination of choice translation algorithm (ELECTRE) and preference organization method for enrichment evaluation (PROMETHEE). However in the above methods, there is no formal procedure for evaluation of weights. There are several other methods to find out weights from pairwise comparison matrices such as logarithmic least squares method and least squares method, but eigenvector method has been found to be most suitable to find out weights from pairwise comparison matrices.

\section{Identification of criteria and hierarchy formation}

A preliminary literature survey was carried out to identify the criteria. Also a questionnaire survey was administered among students. Then, as part of the Delphi study, in the preliminary round questionnaire, open-ended questions on criteria/subcriteria to be considered were included and sent to 25 principals (experts) of engineering colleges in Andhra Pradesh (India). Their responses along with the criteria indicated in the literature survey and questionnaire survey among students were summarized and a list of criteria/subcriteria to be considered was prepared. Then another questionnaire was administered to the experts for addition/removal of criteria. About 15 responses were received in this round, at the end of which 13 criteria were identified.

4.1. The physical significance of the criteria which influence student absenteeism. In the hierarchy shown in Figure 4.1, the first level (Level 0) shows the overall goal of motivating students towards studious habits by reducing student absenteeism. The next level (Level 1) shows the main criteria that cause student absenteeism, and its next level (Level 2) shows the subcriteria under each main criterion. The last level (Level 3) shows alternative solutions to the problem. The physical significance of various criteria/subcriteria is explained below.

(i) Ill health. The student may be absent due to ill health caused frequently like aches (stomach ache, head ache, etc.), common cold, fever, and so forth, and ill health caused by diseases like typhoid, jaundice, and so forth, or the student may have auditory/visual defects.

(ii) Domestic problems. The student may be absent due to domestic problems like death of a near relative sometimes necessitating that the student shoulders additional responsibilities of the family, and unrest between parents.

(iii) Preparation without a teacher. The student may be absent as he/she is capable of preparing for the course without the help of a teacher or the teacher's teaching is demotivating. 


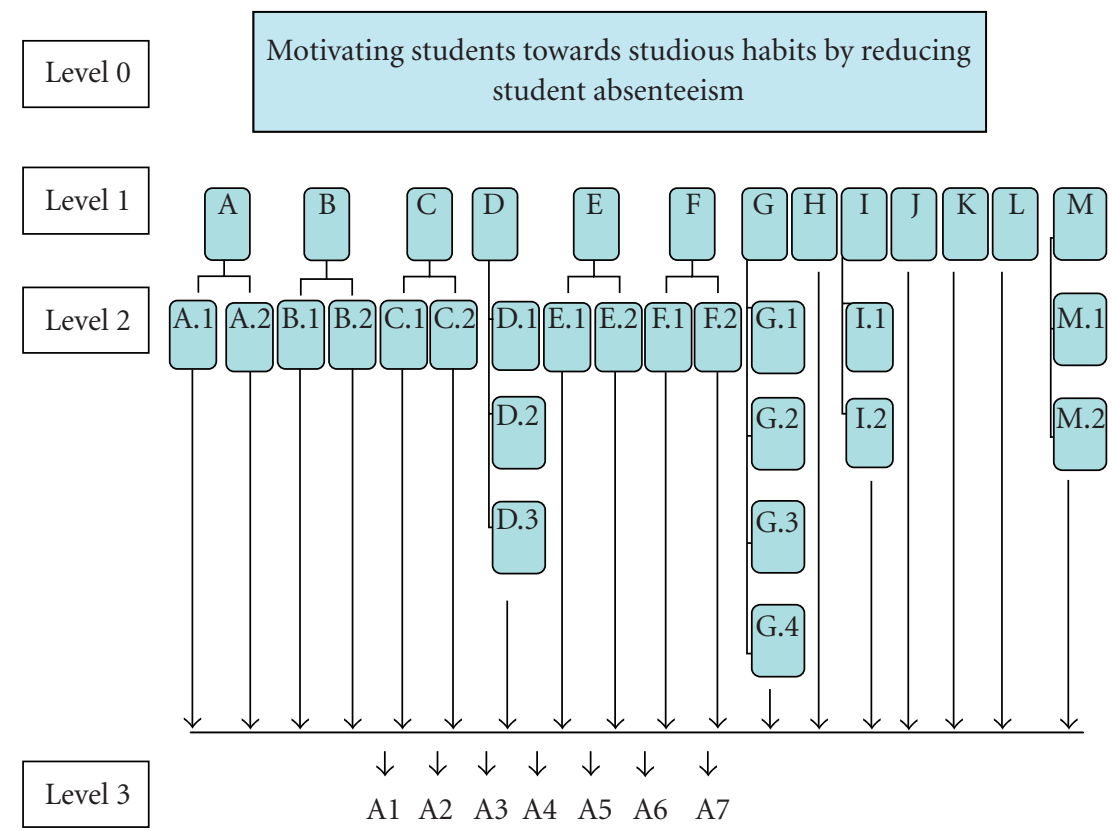

Level 1 : Criteria

A : Ill health

B : Domestic problems

$C$ : Preparation without teacher

D : Lack of motivation

E : Class environment

$\mathrm{F}$ : Socioeconomic factors

$\mathrm{G}$ : Psychological factors

$\mathrm{H}$ : Evaluation system

I : Distractions

$\mathrm{J}$ : Lack of responsibility of student

$\mathrm{K}$ : Irregular conduct of classes

$\mathrm{L}:$ Participation in cocurricular/extracurricular/ cultural activities

M : Participation in W.S./ seminars/conferences
Level 2 : Subcriteria

A.1 : Frequent Ill health

A.2: Ill health once in a way

B.1 : Monetary problems

B.2 : Responsibility being taken up

C.1 : No teacher commitment

C.2: Teacher unprepared

D.1 : Self-motivation

D.2 : Motivation from teachers

D.3 : Motivation from parents

E.1: Proper ventilation

E.2 : Disturbances outside the room

F.1 : Difficulty in changing from regional language to English

F.2: Uneducated parents

G.1 : Influence of bad company

G.2 : Effect of neighboring colleges and their schedules

G.3 : Indiscipline

G.4 : Lack of interest for engineering education

I.1 : Movies/drugs/other attractions

I.2 : Political/communal activities

M.1 : Preparation for GRE/ TOEFL/GATE

M.2 : Preparation for other courses
Level 3 : Alternatives

A1 : Counseling

A2: Infrastructure

A3 : Involvement of parents

A4 : Making lecture more attractive

A5 : Curriculum revision/ better evaluation

A6 : Punishment/ awards for attendance

A7 : Peer pressure

Figure 4.1. Hierarchical decomposition of criteria in student absenteeism. 
(iv) Lack of motivation. The student may be absent as a result of lack of encouragement from teachers/parents or he/she lacks enthusiasm to learn or he/she lacks motivation due to lack of job opportunities as perceived by the student.

(v) Class environment. The student may be absent, as he/she may find the class environment uncomfortable due to poor ventilation or noise/disturbances outside the class.

(vi) Socioeconomic factors. The student may be absent because of socioeconomic factors like having uneducated parents or might belong to economically backward class, lacking finances to meet living expenses, and so forth.

(vii) Psychological factors. The student may be absent because of psychological factors like peer pressure, or is demotivated because neighboring colleges apparently have more comfortable schedules, or he/she is undisciplined (misbehaving in the campus and hence suspended from attending classes), or he/she has no interest in engineering education.

(viii) Evaluation system. The student may be absent as a result of demotivation because he/she perceives that the evaluation system at the end examinations is not objective and that marks are not awarded according to one's ability.

(ix) Distractions. The student may be absent because of many distractions like movies, drugs, cricket, and other amusements. He/she may be involved in communal/political activities.

(x) Lack of responsibility of student. The student may be absent because of lack of sense of responsibility, and he/she does not have proper guidance regarding the course and lacks accountability.

(xi) Irregular conduct of classes. The student may be absent because of irregular conduct of classes and thereby loses interest in attending the college.

(xii) Participation in cocurricular/extracurricular, and cultural activities. The student may be absent as he/she participates in celebration of events/occasions or games/sports or competitions held outside the college.

(xiii) Participation in workshops/seminars/conferences. The student may be absent as he/ she may be participating in external workshops or seminars or conferences or he/she is preparing for examinations like GRE/GATE/TOEFL, and so forth.

The next round of Delphi study was conducted to identify the relative importance of factors that are to be considered to analyze the student absenteeism and other related matters. The method of Saaty [21, 22], described below, that generates a hierarchical alternative solutions is used for analysis.

Based on the criteria formed, a second-round questionnaire was prepared to verify the importance, in consideration with each and every identified criterion, which influences student absenteeism in engineering colleges. Saaty's linguistic scale, given in Table 4.1, was used to collect expert's opinions on pairwise importance of criteria/subcriteria. The hierarchical structure of the criteria along with alternative solutions is given in Figure 4.1. 
Table 4.1. Pairwise comparison scale (AHP Saaty's scale, taken from Saaty [22]).

\begin{tabular}{|c|c|c|}
\hline $\begin{array}{l}\text { Intensity of } \\
\text { importance }\end{array}$ & Definition & Explanation \\
\hline 1 & Equal importance & $\begin{array}{l}\text { Two elements contribute equally to the } \\
\text { property }\end{array}$ \\
\hline 3 & $\begin{array}{l}\text { Moderate importance of } \\
\text { one over another }\end{array}$ & $\begin{array}{l}\text { Experience and judgment slightly } \\
\text { favor one over the other }\end{array}$ \\
\hline 5 & $\begin{array}{l}\text { Essential or strong } \\
\text { importance }\end{array}$ & $\begin{array}{l}\text { Experience and judgment strongly } \\
\text { favor one over another }\end{array}$ \\
\hline 7 & Very strong importance & $\begin{array}{l}\text { An element is strongly favored and its } \\
\text { dominance is demonstrated in practice }\end{array}$ \\
\hline 9 & Extreme importance & $\begin{array}{l}\text { The evidence favoring one element } \\
\text { over another is one of the highest } \\
\text { possible order of affirmation }\end{array}$ \\
\hline $2,4,6,8$ & $\begin{array}{l}\text { Intermediate values between } \\
\text { two adjacent judgments }\end{array}$ & $\begin{array}{l}\text { Comprise is needed between two } \\
\text { judgments }\end{array}$ \\
\hline Reciprocals & \multicolumn{2}{|c|}{$\begin{array}{l}\text { When activity } i \text { compared to } j \text { assigns one of the above numbers, the } \\
\text { activity } j \text { compared to } i \text { assigns its reciprocal }\end{array}$} \\
\hline Rational & \multicolumn{2}{|c|}{ Ratios arising from forcing consistency of judgments } \\
\hline
\end{tabular}

\section{Delphi study with AHP}

5.1. Importance weights of criteria/subcriteria. According to the hierarchy formed in Figure 4.1, a second-round questionnaire was prepared and sent to the 15 experts. Saaty's pairwise scale was used to collect opinions on relative importance of each criterion at each level. The scale is shown in Table 4.1.

Responses from 11 experts are received. The second step is the elicitation of pairwise comparison judgments. Arrange the elements in the second level into a matrix and elicit the judgments from the people who have the problem about the relative importance of the elements with respect to the overall goal.

The importance weights of each of the experts is found using Eigenvector method which is explained in Section 5.2, and the group importance weights is calculated using geometric mean method as explained in Section 5.3.

5.2. Eigenvector method. Suppose we wish to compare a set of " $n$ " objects in pairs according to their relative weights. Let us denote the objects by $A_{11}, A_{22}, \ldots, A_{n n}$ and their weights by $w_{1}, w_{2}, \ldots, w_{n}$. The pairwise comparisons may be represented by a matrix as in Table 5.1.

This matrix has positive entries everywhere and satisfies the reciprocal property

$$
a_{j i}=\frac{1}{a_{i j}}
$$


P. Kousalya et al. 9

Table 5.1. Table of pairwise comparisons.

\begin{tabular}{c|cccc}
\hline & $A_{11}$ & $A_{22}$ & $\cdots$ & $A_{n n}$ \\
\hline$A_{11}$ & $w_{1} / w_{1}$ & $w_{1} / w_{2}$ & $\cdots$ & $w_{1} / w_{n}$ \\
\hline$A_{22}$ & $w_{2} / w_{1}$ & $w_{2} / w_{2}$ & $\cdots$ & $w_{2} / w_{n}$ \\
\hline$\vdots$ & $\vdots$ & $\vdots$ & $\vdots$ & $\vdots$ \\
\hline$A_{n n}$ & $w_{n} / w_{1}$ & $w_{n} / w_{2}$ & $\cdots$ & $w_{n} / w_{n}$ \\
\hline
\end{tabular}

It is called a reciprocal matrix. If we multiply this matrix by the transpose of the vector

$$
w^{T}=\left(w_{1}, w_{2}, \ldots, w_{n}\right)
$$

we obtain the vector $n w$. Our problem takes the form

$$
A w=n w .
$$

We started with the assumption that $w$ was given. But if we only had $A$ and wanted to recover $w$, we would have to solve the system

$$
(A-n I) w=0
$$

in the unknown $w$. This has a nonzero solution if $n$ is an eigenvalue of $A$, that is, it is a root of the characteristic equation of $A$. But $A$ has unit rank since every row is a constant multiple of the first row. Thus all the eigenvalues $\lambda_{i}, i=1,2, \ldots, n$, of $A$ are zero except one.

Also it is known that

$$
\sum_{i=1}^{n} \lambda_{i}=\operatorname{tr}(A)=n, \quad \lambda_{i}=0, \lambda_{i} \neq \lambda_{\text {max }} .
$$

The solution $w$ of this problem is any column of $A$. These solutions differ by a multiplicative constant. However, this solution is normalized so that its components sum to unity. The result is a unique solution no matter which column is used. The matrix $A$ satisfies the cardinal consistency property

$$
a_{i j} a_{j k}=a_{i k}
$$

and is called consistent. If we are given any row of $A$, we can determine the rest of the entries from this relation. 
Table 5.2. Table of pairwise comparisons.

\begin{tabular}{c|cccc}
\hline & $A_{11}$ & $A_{22}$ & $\cdots$ & $A_{n n}$ \\
\hline$A_{11}$ & $a_{11}$ & $a_{12}$ & $\cdots$ & $a_{1 n}$ \\
\hline$A_{22}$ & $a_{21}$ & $a_{22}$ & $\cdots$ & $a_{2 n}$ \\
\hline$\vdots$ & $\vdots$ & $\vdots$ & $\vdots$ & $\vdots$ \\
\hline$A_{n n}$ & $a_{n 1}$ & $a_{n 2}$ & $\cdots$ & $a_{n n}$ \\
\hline
\end{tabular}

5.3. Geometric mean method. Obtain the geometric row means of each row as

$$
\begin{gathered}
A_{11}=\left(a_{11}^{*} a_{12}^{*} a_{13}^{*} \ldots * a_{1 n}\right)^{1 / n}, \\
A_{22}=\left(a_{21}^{*} a_{22}^{*} a_{23}^{*} \ldots * a_{2 n}\right)^{1 / n}, \\
\vdots \\
A_{n n}=\left(a_{n 1}^{*} a_{n 2}^{*} a_{n 3}^{*} \ldots * a_{n n}\right)^{1 / n} .
\end{gathered}
$$

Obtain the normalized geometric row means as

$$
\mathrm{GMM}=\left[A_{11} /\left(A_{11+} A_{22+} \ldots A_{n n}\right), A_{22} /\left(A_{11+} A_{22+\ldots} A_{n n}\right), \ldots, A_{n n} /\left(A_{11+} A_{22+} \ldots A_{n n}\right)\right]^{T}
$$

This gives the required importance weights of criteria/subcriteria or the alternatives under criteria/subcriteria.

Next we move to the pairwise comparisons of the elements in the lowest level.

The elements to be compared pairwise are the alternative solutions with respect to how much better one is than the other in satisfying each criterion/subcriterion in level 2 . Thus there will be twenty five $7 \times 7$ matrices of judgments since there are 25 elements in level 2 and 7 elements to be pairwise compared for each element.

5.4. Ratio scales from reciprocal pairwise comparison matrices. In Table 5.3 , the criteria are named as A, B, C, .., M and their subcriteria are named as A.1, A.2, B.1, B.2,.., M.1, M.2. The opinions of experts on criteria/subcriteria are weighed which are given in Table 5.3 and are ranked for each of the experts Exp: 2, Exp: 5, Exp: 8, Exp: 10, and Exp: 11. The rankings of the criteria/subcriteria are shown in Table 5.4 from which it could be observed that the criterion participation in workshops/seminars/conferences $(\mathrm{M})$ is among the first nine, which is given by three experts. The criterion evaluation system $(\mathrm{H})$ is among the first nine, which is given by five experts. The criterion lack of responsibility of the student $(\mathrm{J})$ is among the first nine, which is given by five experts. The criterion distractions (I) is among the first nine, which is given by three experts. The criterion lack of motivation (D) is among the first nine, which is given by three experts. The criterion, 
Table 5.3. Experts' opinions on importance of different criteria/subcriteria.

\begin{tabular}{|c|c|c|c|c|c|c|c|}
\hline & Criteria & Exp: 2 & Exp: 5 & Exp: 8 & Exp: 10 & Exp: 11 & $\begin{array}{l}\text { Group } \\
\text { weights }\end{array}$ \\
\hline A & Ill health & 0.12199 & 0.01769 & 0.04415 & 0.1294 & 0.0168 & 0.05563 \\
\hline B & Domestic problems & 0.117356 & 0.05269 & 0.04807 & 0.04236 & 0.02971 & 0.06257 \\
\hline $\mathrm{C}$ & $\begin{array}{l}\text { Preparation without } \\
\text { teacher }\end{array}$ & 0.04549 & 0.0498 & 0.0764 & 0.03738 & 0.02891 & 0.05454 \\
\hline $\mathrm{D}$ & Lack of motivation & 0.09476 & 0.2908 & 0.06361 & 0.0289 & 0.02427 & 0.07975 \\
\hline $\mathrm{E}$ & Class environment & 0.022896 & 0.1339 & 0.0889 & 0.0238 & 0.0329 & 0.05600 \\
\hline $\mathrm{F}$ & $\begin{array}{l}\text { Socioeconomic } \\
\text { factors }\end{array}$ & 0.062902 & 0.0655 & 0.08027 & 0.05472 & 0.04418 & 0.07288 \\
\hline G & Psychological factors & 0.099113 & 0.0695 & 0.05112 & 0.0362 & 0.06029 & 0.07235 \\
\hline $\mathrm{H}$ & Evaluation system & 0.137018 & 0.13115 & 0.06718 & 0.0639 & 0.0828 & 0.11048 \\
\hline I & Distractions & 0.03319 & 0.03238 & 0.1463 & 0.11589 & 0.09457 & 0.08488 \\
\hline $\mathrm{J}$ & $\begin{array}{l}\text { Lack of responsibility } \\
\text { of student }\end{array}$ & 0.11414 & 0.05883 & 0.0863 & 0.0595 & 0.0722 & 0.09154 \\
\hline K & $\begin{array}{l}\text { Irregular conduct } \\
\text { of classes }\end{array}$ & 0.0601 & 0.0382 & 0.01968 & 0.0765 & 0.0968 & 0.06124 \\
\hline $\mathrm{L}$ & $\begin{array}{l}\text { Participation in co } \\
\text { curricular/extra } \\
\text { curricular/cultural } \\
\text { activities }\end{array}$ & 0.042731 & 0.02958 & 0.0226 & 0.12947 & 0.21228 & 0.07265 \\
\hline M & $\begin{array}{l}\text { Participation in } \\
\text { W.S./seminars/ } \\
\text { conferences }\end{array}$ & 0.04828 & 0.02958 & 0.20542 & 0.20114 & 0.20408 & 0.12542 \\
\hline A.1 & Frequent ill health & 0.833 & 0.83 & 0.5 & 0.751 & 0.5 & 0.70255 \\
\hline A. 2 & $\begin{array}{l}\text { Ill health once } \\
\text { in a way }\end{array}$ & 0.167 & 0.17 & 0.5 & 0.249 & 0.5 & 0.29749 \\
\hline B. 1 & Monetary problems & 0.167 & 0.5 & 0.5 & 0.5 & 0.5 & 0.42036 \\
\hline B. 2 & $\begin{array}{l}\text { Responsibility being } \\
\text { taken up }\end{array}$ & 0.833 & 0.5 & 0.5 & 0.5 & 0.5 & 0.57971 \\
\hline C. 1 & $\begin{array}{l}\text { No teacher } \\
\text { commitment }\end{array}$ & 0.5 & 0.25 & 0.875 & 0.5 & 0.25 & 0.48746 \\
\hline C. 2 & Teacher unprepared & 0.5 & 0.75 & 0.125 & 0.5 & 0.75 & 0.51259 \\
\hline D. 1 & Self-motivation & 0.071 & 0.05 & 0.333 & 0.202 & 0.22 & 0.14884 \\
\hline D. 2 & $\begin{array}{l}\text { Motivation from } \\
\text { teachers }\end{array}$ & 0.464 & 0.48 & 0.333 & 0.292 & 0.56 & 0.44196 \\
\hline D.3 & $\begin{array}{l}\text { Motivation from } \\
\text { parents }\end{array}$ & 0.464 & 0.484 & 0.333 & 0.506 & 0.22 & 0.40924 \\
\hline E. 1 & Proper ventilation & 0.167 & 0.25 & 0.5 & 0.249 & 0.5 & 0.31825 \\
\hline E. 2 & $\begin{array}{l}\text { Disturbances outside } \\
\text { the room }\end{array}$ & 0.833 & 0.75 & 0.5 & 0.751 & 0.5 & 0.68182 \\
\hline
\end{tabular}


Table 5.3. Continued.

\begin{tabular}{|c|c|c|c|c|c|c|c|}
\hline & Criteria & Exp: 2 & Exp: 5 & Exp: 8 & Exp: 10 & Exp: 11 & $\begin{array}{l}\text { Group } \\
\text { weights }\end{array}$ \\
\hline F.1 & $\begin{array}{l}\text { Difficulty in changing } \\
\text { from regional language } \\
\text { to English }\end{array}$ & 0.167 & 0.5 & 0.875 & 0.5 & 0.77 & 0.57680 \\
\hline F.2 & Uneducated parents & 0.833 & 0.5 & 0.125 & 0.5 & 0.23 & 0.42329 \\
\hline G.1 & $\begin{array}{l}\text { Influence of } \\
\text { bad company }\end{array}$ & 0.214 & 0.62 & 0.601 & 0.114 & 0.24 & 0.35065 \\
\hline G.2 & $\begin{array}{l}\text { Effect of neighboring } \\
\text { colleges schedules }\end{array}$ & 0.095 & 0.14 & 0.086 & 0.344 & 0.11 & 0.16009 \\
\hline G.3 & Indiscipline & 0.214 & 0.11 & 0.086 & 0.198 & 0.54 & 0.22089 \\
\hline G.4 & $\begin{array}{l}\text { Lack of interest for } \\
\text { engineering education }\end{array}$ & 0.477 & 0.14 & 0.227 & 0.344 & 0.11 & 0.26843 \\
\hline I. 1 & $\begin{array}{l}\text { Movies/drugs/other } \\
\text { attractions }\end{array}$ & 0.833 & 0.25 & 0.833 & 0.249 & 0.83 & 0.62704 \\
\hline $\mathrm{I} .2$ & $\begin{array}{l}\text { Communal/political } \\
\text { activities }\end{array}$ & 0.167 & 0.75 & 0.167 & 0.751 & 0.17 & 0.37300 \\
\hline M.1 & $\begin{array}{l}\text { Preparation for } \\
\text { GRE/TOEFL/GATE }\end{array}$ & 0.9 & 0.25 & 0.875 & 0.751 & 0.25 & 0.64796 \\
\hline M.2 & $\begin{array}{l}\text { Preparation for } \\
\text { other courses }\end{array}$ & 0.1 & 0.75 & 0.125 & 0.249 & 0.75 & 0.35208 \\
\hline
\end{tabular}

socioeconomic factors (F), among the first nine, which is given by five experts. The criterion participation in cocurricular/extracurricular/cultural activities (L) is among the first nine criteria, which is given by two experts. The criterion psychological factors $(\mathrm{G})$ is among the first nine criteria, which is given by four experts. The criterion domestic problems (B) is among the first nine, which is given by three experts.

Though exact consensus was not found while ranking the criteria, it could be observed that all the five experts have ranked the same criteria as the first nine criteria, and this ranking is almost the same as the opinions of the group. This shows that in judging aggregate criteria, panelists are not able to judge well, but when the aggregate criteria are disintegrated and formed as the operational subcriteria, they are able to judge well and have almost expressed the same opinion leading to high consensus as seen in Table 5.4-ranks of criteria/subcriteria. Therefore we feel that even if sample increases the same opinion will arrive.

The final ranking of the criteria/subcriteria is shown in Table 5.4 where in the last column named as Group, are the opinions of the group as calculated by geometric mean method which is explained in Section 5.3. 
It is observed that all the five experts have ranked participation in workshops/seminars/ conferences, evaluation system, lack of responsibility of the student, distractions, lack of motivation, socioeconomic factors, participation in cocurricular/extracurricular/cultural activities, psychological factors, and domestic problems (M, H, J, I, D, F, L, G, B), as the first nine criteria, which is nearly the same as that of the group. Also it can be seen that, when the rankings of the subcriteria are considered, there is a good amount of consensus among the experts' opinions.

5.5. Alternative solutions to student absenteeism. From literature survey, experts' opinions, and journals' surveys $[1,2,20]$, some alternative solutions which are relevant to the criteria, for reducing student absenteeism were identified. By Delphi study, the alternatives are then sent to the experts for consensus and finally the following were shortlisted. The alternatives considered for motivating students to reduce student absenteeism and stimulating studious/efficient-learning processes in them are as follows:

(i) counseling,

(ii) infrastructure,

(iii) involvement of parents,

(iv) making lecture more attractive,

(v) curriculum-revision/better evaluation,

(vi) punishments/awards for attendance,

(vii) peer pressure.

5.5.1. The physical significance of alternatives with respect to the criteria/subcriteria. The physical significance of alternatives with respect to the criteria/subcriteria is explained below.

Counseling. A student who has certain domestic problems, who lacks self-motivation, who lacks motivation from teachers/parents; or who has difficulty in changing from regional language to English, who has bad company; or who is undisciplined or who is involved in some political/communal activities needs counseling.

Infrastructure. Good infrastructure like well-equipped labs good library facilities is to be provided. Classrooms need to have proper ventilation. Frequent ill health like common fevers, headaches, and so forth can be cured with some first aid and medical facilities.

Involvement of parents. Parents need to check their wards' attendance to the classes their performance in the examinations regularly. Parents can motivate their wards to the maximum extent and see that they are not involved in a bad company, or in political/communal activities.

Making lecture more attractive. Certain factors like disturbances outside the class room, lack of interest for engineering education, distractions like movies/drugs, or other attractions, involvement in political/communal activities can be curbed by making lecture more attractive.

Curriculum revision/better evaluation. Certain factors like evaluation system can be changed by better evaluation techniques that can be adopted by universities. Curriculum has to be revised regularly so that students can participate in workshops, seminars, or conferences. 
14 Student absenteeism using AHP

Table 5.4. Ranks of criteria/subcriteria.

\begin{tabular}{|c|c|c|c|c|c|c|}
\hline \multicolumn{7}{|c|}{ Level: 1} \\
\hline Rank & Exp: 2 & Exp: 5 & Exp: 8 & Exp: 10 & Exp: 11 & Group \\
\hline 1 & $\mathrm{H}$ & $\mathrm{D}$ & $\mathrm{M}$ & $\mathrm{M}$ & $\mathrm{L}$ & $\mathrm{M}$ \\
\hline 2 & A & $\mathrm{E}$ & I & $\mathrm{L}$ & M & $\mathrm{H}$ \\
\hline 3 & B & $\mathrm{H}$ & $\mathrm{E}$ & A & K & $\mathrm{J}$ \\
\hline 4 & $\mathrm{~J}$ & G & $\mathrm{J}$ & I & I & I \\
\hline 5 & G & $\mathrm{F}$ & F & $\mathrm{K}$ & $\mathrm{H}$ & $\mathrm{D}$ \\
\hline 6 & $\mathrm{D}$ & $\mathrm{J}$ & $\mathrm{C}$ & $\mathrm{H}$ & $\mathrm{J}$ & $\mathrm{F}$ \\
\hline 7 & F & B & $\mathrm{H}$ & $\mathrm{J}$ & G & $\mathrm{L}$ \\
\hline 8 & $\mathrm{~K}$ & $\mathrm{C}$ & $\mathrm{D}$ & F & F & G \\
\hline 9 & M & K & G & B & E & B \\
\hline 10 & $\mathrm{C}$ & I & B & $\mathrm{C}$ & B & $\mathrm{K}$ \\
\hline 11 & $\mathrm{~L}$ & $\mathrm{~L}$ & A & G & $\mathrm{C}$ & $\mathrm{E}$ \\
\hline 12 & I & M & $\mathrm{L}$ & $\mathrm{D}$ & $\mathrm{D}$ & A \\
\hline 13 & E & A & K & E & A & C \\
\hline \multicolumn{7}{|c|}{ Level: 2} \\
\hline 1 & A. 1 & A. 1 & A. 1 & A. 1 & A. 1 & A. 1 \\
\hline 2 & A. 2 & A. 2 & A. 2 & A. 2 & A. 2 & A. 2 \\
\hline 1 & B. 2 & B. 2 & B. 2 & B. 2 & B. 2 & B. 2 \\
\hline 2 & B. 1 & B. 1 & B. 1 & B. 1 & B. 1 & B. 1 \\
\hline 1 & C. 2 & C. 2 & C. 1 & C. 1 & C. 2 & C. 2 \\
\hline 2 & C. 1 & C. 1 & С. 2 & С. 2 & C. 1 & C.1 \\
\hline 1 & D. 1 & D. 2 & D. 2 & D. 3 & D. 2 & D.2 \\
\hline 2 & D. 2 & D. 3 & D. 3 & D. 2 & D. 3 & D. 3 \\
\hline 3 & D. 3 & D. 1 & D. 1 & D. 1 & D. 1 & D.1 \\
\hline 1 & E. 2 & E. 2 & E. 2 & E. 2 & E. 2 & E. 2 \\
\hline 2 & E.1 & E.1 & E.1 & E.1 & E.1 & E.1 \\
\hline 1 & F. 2 & F.1 & F.1 & F.1 & F. 2 & F.1 \\
\hline 2 & F.1 & F. 2 & F. 2 & F. 2 & F.1 & F. 2 \\
\hline 1 & G.4 & G.1 & G.1 & G.4 & G.3 & G.1 \\
\hline 2 & G.3 & G. 2 & G.4 & G.2 & G.1 & G.4 \\
\hline 3 & G.1 & G.4 & G.2 & G.3 & G.4 & G.3 \\
\hline 4 & G.2 & G.3 & G.3 & G.1 & G.2 & G.2 \\
\hline 1 & I.1 & I. 2 & I. 1 & I. 2 & I. 1 & I. 1 \\
\hline 2 & I. 2 & I. 1 & I. 2 & I. 1 & I. 2 & I. 2 \\
\hline 1 & M.1 & M.2 & M.1 & M.1 & M.2 & M.1 \\
\hline 2 & M.2 & M.1 & M.2 & M.2 & M.1 & M.2 \\
\hline
\end{tabular}

Punishments/awards for attendance. Giving awards for good attendance can motivate the student. By giving punishments from the beginning of the academic year for poor 
attendance, factors like lack of responsibility of the student and participation in cocurricular/extra curricular/cultural activities can be reduced to some extent.

Peer pressure. Certain factors like influence of bad company, indiscipline, distractions like movies/drugs, or other attractions can be either reduced increased by peer pressure. Also, student's involvement in communal/political activities can be reduced if peer pressure is exerted positively.

5.6. Consistency test. The validity of expert's opinions on importance of criteria, alternatives versus subjective criteria, is verified by Saaty's consistency test.

Saaty defines the consistency index (C.I) as

$$
\mathrm{C} . \mathrm{I}=\frac{\left(\lambda_{\max }-n\right)}{(n-1)}
$$

and their mean C.I value, called the random index (R.I) was computed as shown in Table 5.5. Using these values, consistency ratio (C.R) is defined as the ratio of C.I to R.I. Thus C. $R$ is a measure of how a given matrix compares to a purely random matrix in terms of their C.Is.

Therefore,

$$
\mathrm{C} . \mathrm{R}=\frac{\mathrm{C} . \mathrm{I}}{\mathrm{R} . \mathrm{I}}
$$

The acceptable CR range varies according to the size of the matrix, that is, 0.05 for a $3 \times 3$ matrix, 0.08 for a $4 \times 4$ matrix, and 0.1 for all larger matrices, for $n \geq 5$ (Saaty 1980 [22]) if the value of CR is equal to, or less than, that value, it implies that the evaluation within the matrix is acceptable or indicates a good level of consistency in the comparative judgments represented in that matrix. If $\mathrm{CR}$ is more than that acceptable value, inconsistency of the judgments within the matrix has occurred and the evaluation process should be reviewed.

A value of C.R $\leq 0.1$ is considered acceptable; and larger values require the decision maker to reduce the inconsistencies by revising judgments. First C.I of each pairwise matrix was found.

The average random consistency index is given in Table 5.5 where the first column corresponds to the size of the matrix and the second column, their corresponding random consistency indices for different size of the matrices.

5.6.1. Hierarchy consistency index. The hierarchy consistency index for each expert was calculated by multiplying C.I under each criterion with its global weight and adding these for the entire hierarchy. These are shown for each expert in the second column of Table 5.6.

5.6.2. Hierarchy random consistency. Hierarchy random consistency is obtained by multiplying the random indices under each criterion for each expert, with its global weight and by adding these for the entire hierarchy. These are shown for each expert in the third column of Table 5.6. 
Table 5.5. Average random consistency index (RI) based on matrix size (adapted from Saaty 1980 [22]).

\begin{tabular}{c|c}
\hline Size of matrix $(n)$ & Random consistency index $(\mathrm{RI})$ \\
\hline 1 & 0 \\
2 & 0 \\
3 & 0.52 \\
4 & 0.89 \\
5 & 1.11 \\
6 & 1.25 \\
7 & 1.35 \\
8 & 1.40 \\
9 & 1.45 \\
10 & 1.49 \\
11 & 1.51 \\
12 & 1.48 \\
13 & 1.56 \\
\hline
\end{tabular}

Table 5.6. Hierarchy consistency of experts' opinions.

\begin{tabular}{l|ccc}
\hline Experts & $\begin{array}{c}\text { Hierarchy consistency } \\
\text { index }\end{array}$ & $\begin{array}{c}\text { Hierarchy random } \\
\text { consistency }\end{array}$ & $\begin{array}{c}\text { Hierarchy consistency } \\
\text { ratio }\end{array}$ \\
\hline Expert 2 & 0.162241 & 0.172812 & 0.93889 \\
Expert 8 & 0.133374 & 0.144912 & 0.92037 \\
Expert 10 & 0.18394 & 0.1964938 & 0.93611 \\
Expert 11 & 0.168443 & 0.182785 & 0.921536 \\
\hline
\end{tabular}

5.6.3. Hierarchy consistency ratio. The hierarchy consistency ratio of each expert is the ratio of hierarchy consistency index to hierarchy random consistency. It is the ratio of the second column elements to the third column elements for each expert. The hierarchy consistency ratio of each expert is given in the fourth column of Table 5.6. These terms like hierarchy consistency index, hierarchy random consistency, and hierarchy consistency ratio are cited in [8]. Table 5.6 shows that the hierarchy consistency ratio of experts' ranges from 0.92037 (Expert 8) to 0.93889 (Expert 2). Hence, there is a good amount of consistency in the opinions of the experts.

5.7. Preferential weights of alternatives. Using Saaty's Eigenvector method, appropriateness weights of alternatives [16] under each criterion/subcriterion are calculated which is shown in Table 5.7. The composite weights of alternatives are found by multiplying the appropriateness weights under each criterion with that criterion's global importance weight. By adding each such composite weight for all the criteria, the preferential weights of alternatives for each expert are found.

The alternatives were then sent to 11 of the experts who had responded to the first two questionnaires out of which 4 have responded, which is shown in Table 5.12. The 
Table 5.7. Appropriateness weights of alternatives under different criteria (pay-off matrix of alternatives).

\begin{tabular}{|c|c|c|c|c|c|c|c|}
\hline $\begin{array}{l}\text { Criteria } \\
\text { name }\end{array}$ & Counseling & Infrastructure & $\begin{array}{l}\text { Involvement } \\
\text { of parents }\end{array}$ & $\begin{array}{l}\text { Making } \\
\text { lecture } \\
\text { more } \\
\text { attractive }\end{array}$ & $\begin{array}{l}\text { Curriculum } \\
\text { revision/ } \\
\text { better } \\
\text { evaluation }\end{array}$ & $\begin{array}{l}\text { Punishment/ } \\
\text { awards for } \\
\text { attendance }\end{array}$ & $\begin{array}{l}\text { Peer } \\
\text { pressure }\end{array}$ \\
\hline $\begin{array}{l}\text { Frequent ill } \\
\text { health }\end{array}$ & 0.117143 & 0.07903 & 0.3583 & 0.17743 & 0.12113 & 0.07903 & 0.0765 \\
\hline $\begin{array}{l}\text { Ill health } \\
\text { once } \\
\text { in a way }\end{array}$ & 0.179155 & 0.16223 & 0.35077 & 0.090198 & 0.055283 & 0.09847 & 0.0638 \\
\hline $\begin{array}{l}\text { Monetary } \\
\text { problems }\end{array}$ & 0.192465 & 0.103823 & 0.233627 & 0.105107 & 0.077486 & 0.124175 & 0.1633 \\
\hline $\begin{array}{l}\text { Responsibility } \\
\text { being } \\
\text { taken up }\end{array}$ & 0.1823 & 0.0867 & 0.3281 & 0.09296 & 0.0615 & 0.13108 & 0.1171 \\
\hline $\begin{array}{l}\text { No teacher } \\
\text { commitment }\end{array}$ & 0.111286 & 0.070699 & 0.192198 & 0.270618 & 0.109607 & 0.128702 & 0.1169 \\
\hline $\begin{array}{l}\text { Teacher } \\
\text { unprepared }\end{array}$ & 0.15325 & 0.090006 & 0.095045 & 0.109872 & 0.148824 & 0.205611 & 0.1974 \\
\hline $\begin{array}{l}\text { Self- } \\
\text { motivation }\end{array}$ & 0.057625 & 0.048601 & 0.110035 & 0.234376 & 0.150293 & 0.179135 & 0.21993 \\
\hline $\begin{array}{l}\text { Motivation } \\
\text { from } \\
\text { teachers }\end{array}$ & 0.191572 & 0.070598 & 0.064668 & 0.264597 & 0.195396 & 0.13942 & 0.07385 \\
\hline $\begin{array}{l}\text { Motivation } \\
\text { from } \\
\text { parents }\end{array}$ & 0.188441 & 0.056527 & 0.269895 & 0.067982 & 0.048914 & 0.124845 & 0.24342 \\
\hline $\begin{array}{l}\text { Proper } \\
\text { ventilation }\end{array}$ & 0.133052 & 0.23567 & 0.08249 & 0.162565 & 0.087974 & 0.146686 & 0.15154 \\
\hline $\begin{array}{l}\text { Disturbances } \\
\text { outside } \\
\text { the room }\end{array}$ & 0.132484 & 0.074174 & 0.116045 & 0.158429 & 0.097669 & 0.241865 & 0.1794 \\
\hline $\begin{array}{l}\text { Difficulty in } \\
\text { changing } \\
\text { from regional } \\
\text { language to } \\
\text { English }\end{array}$ & 0.194665 & 0.060937 & 0.157944 & 0.148249 & 0.077168 & 0.119836 & 0.2412 \\
\hline $\begin{array}{l}\text { Uneducated } \\
\text { parents }\end{array}$ & 0.195863 & 0.087397 & 0.144273 & 0.051458 & 0.048558 & 0.220939 & 0.2515 \\
\hline $\begin{array}{l}\text { Influence of } \\
\text { bad company }\end{array}$ & 0.246516 & 0.036362 & 0.200814 & 0.055697 & 0.038414 & 0.167329 & 0.2548 \\
\hline $\begin{array}{l}\text { Effect of } \\
\text { neighboring } \\
\text { colleges and } \\
\text { their schedules }\end{array}$ & 0.113408 & 0.129163 & 0.111353 & 0.070307 & 0.048784 & 0.193087 & 0.3339 \\
\hline
\end{tabular}


Table 5.7. Continued.

\begin{tabular}{l|l|l|l|l|l|l|l}
\hline $\begin{array}{l}\text { Criteria } \\
\text { name }\end{array}$ & Counseling & Infrastructure & $\begin{array}{l}\text { Involvement } \\
\text { of parents }\end{array}$ & $\begin{array}{l}\text { Making } \\
\text { lecture } \\
\text { more } \\
\text { attractive }\end{array}$ & $\begin{array}{l}\text { Curriculum } \\
\text { revision/ } \\
\text { better } \\
\text { evaluation }\end{array}$ & $\begin{array}{l}\text { Punishment/ } \\
\text { awards for } \\
\text { attendance }\end{array}$ & $\begin{array}{l}\text { Peer } \\
\text { pressure }\end{array}$ \\
\hline Indiscipline & 0.206655 & 0.039782 & 0.163641 & 0.071292 & 0.039553 & 0.195114 & 0.28402 \\
\hline $\begin{array}{l}\text { Lack of interest } \\
\text { for engineering } \\
\text { education }\end{array}$ & 0.222444 & 0.11299 & 0.064943 & 0.267742 & 0.11069 & 0.09201 & 0.12918 \\
\hline $\begin{array}{l}\text { Evaluation } \\
\text { system }\end{array}$ & 0.163557 & 0.089249 & 0.09404 & 0.156679 & 0.269963 & 0.102874 & 0.123681 \\
\hline $\begin{array}{l}\text { Movies/drugs/ } \\
\text { other attractions }\end{array}$ & 0.14335 & 0.055053 & 0.219261 & 0.077354 & 0.052669 & 0.183577 & 0.268824 \\
\hline $\begin{array}{l}\text { Communal/ } \\
\text { political } \\
\text { activities }\end{array}$ & 0.232943 & 0.042352 & 0.188434 & 0.088275 & 0.045563 & 0.155462 & 0.246989 \\
\hline $\begin{array}{l}\text { Lack of } \\
\text { responsibility } \\
\text { of student }\end{array}$ & 0.267693 & 0.050423 & 0.237966 & 0.069042 & 0.045805 & 0.129901 & 0.199179 \\
\hline $\begin{array}{l}\text { Irregular } \\
\text { conduct } \\
\text { of classes }\end{array}$ & 0.054949 & 0.122851 & 0.198369 & 0.068198 & 0.101243 & 0.220359 & 0.234017 \\
\hline $\begin{array}{l}\text { Participation in } \\
\text { cocurricular/ } \\
\text { extracurricular/ } \\
\text { cultural activities }\end{array}$ & 0.104304 & 0.25812 & 0.114848 & 0.104589 & 0.147653 & 0.127204 & 0.143348 \\
\hline $\begin{array}{l}\text { Preparation for } \\
\text { GRE/TOEF/ } \\
\text { GATE }\end{array}$ & 0.204351 & 0.094785 & 0.141297 & 0.118462 & 0.065973 & 0.160486 & 0.214662 \\
\hline $\begin{array}{l}\text { Preparation for } \\
\text { other courses }\end{array}$ & 0.269324 & 0.151633 & 0.079207 & 0.095111 & 0.062726 & 0.107481 & 0.234608 \\
\hline & & & & & & & \\
\hline
\end{tabular}

opinions of one of the experts on the alternatives under each criterion/subcriterion are shown in Tables 5.8, 5.9, 5.10, and 5.11. Similarly the opinions of the other three experts are obtained for alternatives under each criterion/subcriteria. The preferential weights of alternatives [16] with respect to each criteria/subcriteria are found for each expert, which is shown in Table 5.12 .

The GMM values, which are shown in Table 5.12, are the group opinions of the four experts (who have responded for the opinions of alternatives under each criterion/subcriterion) for the alternatives with respect to each of the criteria/subcriteria.

These opinions are ranked for each expert under each alternative (preferential ranks) [16] and are compared with the GMM ranks, which are shown in Table 5.13. 
Table 5.8. Experts' opinions on alternatives with respect to different criteria.

\begin{tabular}{|c|c|c|c|c|c|c|c|c|c|c|c|c|c|c|c|c|c|}
\hline \multicolumn{9}{|c|}{ A.1: Frequent ill health } & \multicolumn{9}{|c|}{ A.2: Ill health once in a way } \\
\hline & A1 & $\mathrm{A} 2$ & A3 & A4 & A5 & A6 & A7 & $\begin{array}{l}\text { Priority } \\
\text { vector }\end{array}$ & & A1 & A2 & A3 & A4 & A5 & A6 & A7 & $\begin{array}{l}\text { Priority } \\
\text { vector }\end{array}$ \\
\hline 1 & 1 & .33 & 0.5 & 1 & 5 & 4 & 1 & & 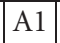 & & 0.33 & 0.33 & J & & 7 & & 0.1532 \\
\hline 12 & 3 & 1 & 3 & E & 5 & 7 & 5 & & & & & & & & & & \\
\hline 3 & 2 & .33 & 1 & 4 & 5 & 1 & $J$ & & & - & & & 5 & & & & \\
\hline 4 & 1 & .2 & 0.25 & 1 & 0.3 & 1 & 0.5 & & & 0.33 & 0.14 & 0.2 & 1 & & 7 & 3 & \\
\hline 5 & 0.2 & & 0.2 & 3 & 1 & 0.3 & 1 & & & 0.2 & 0.14 & 0.14 & 0.2 & & 0.33 & 0.33 & \\
\hline 6 & 0.3 & 0.14 & 0.25 & 1 & 4 & 1 & 1 & & & 0.14 & 0.11 & 0.11 & 0.14 & & 1 & & \\
\hline 47 & 1 & 0.2 & 0.33 & 2 & 1 & 1 & 1 & & A7 & 0.33 & 0.14 & 0.2 & 0.33 & 3 & 0.33 & 1 & \\
\hline \multicolumn{9}{|c|}{$\lambda \max =7.9023$, C.I $=0.150383$, C.R $=0.111395$} & \multicolumn{9}{|c|}{$\lambda \max =7.9236$, C.I $=0.153933$, C. $\mathrm{R}=0.114024$} \\
\hline \multicolumn{9}{|c|}{ B.1: Monetary problems } & \multicolumn{9}{|c|}{ B.2: Responsibility being taken up } \\
\hline & A1 & A2 & A3 & A4 & A5 & A6 & A7 & & & A & A2 & A3 & A4 & A5 & A6 & A7 & \\
\hline A1 & 1 & 5 & 0 . & 5 & 7 & . & 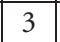 & & & & 7 & 3 & 5 & & 3 & & \\
\hline A2 & 0.2 & 1 & 0.14 & 3 & 5 & 7 & 3 & & & & 1 & 0.14 & & & & & \\
\hline 3 & 5 & 7 & 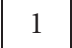 & 7 & 9 & 7 & $J$ & & & & 7 & 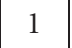 & & & & & \\
\hline A4 & 0.2 & 0.33 & 0.14 & 1 & 1 & 3 & 0.2 & & 4 & 0 & 0.2 & 0.14 & & & 5 & & \\
\hline A5 & 0.1 & & 0.11 & 1 & 1 & 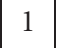 & 0 & & & & 0.14 & 0.11 & 0. & & 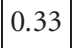 & & \\
\hline A6 & 0.1 & 14 & 0.14 & 0 & 1 & 1 & 0.1 & & A6 & 0.33 & 0.14 & 0.11 & 0.2 & 3 & 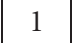 & 33 & \\
\hline A7 & 0.3 & 0.33 & 0.2 & 5 & 7 & 7 & 1 & & A7 & 0.2 & 0.33 & 0.33 & 0.33 & & & & \\
\hline \multicolumn{9}{|c|}{$\lambda \max =7.9827$, C.I $=0.163783$, C.R $=0.121321$} & \multicolumn{9}{|c|}{$\lambda \max =8.6666$, C.I $=0.277767$, C. $R=0.205753$} \\
\hline \multicolumn{9}{|c|}{ C.1: No teacher commitment } & \multicolumn{9}{|c|}{ C.2: Teacher unprepared } \\
\hline & A1 & A2 & A3 & A4 & A5 & A6 & A7 & & & A1 & A2 & A3 & A4 & A5 & A6 & A7 & \\
\hline A1 & 1 & & & 0 & 0.3 & 2 & 3 & & & & 0.2 & 0.2 & 0.11 & 0.2 & & 0.5 & \\
\hline 42 & 5 & 1 & 0.3 & 0 & 0.3 & 5 & & & & & 1 & & & 1 & & & \\
\hline A3 & 3 & 3 & 1 & 0 & 3 & 5 & & & & 5 & 0. & 1 & 3 & 0.2 & 0.2 & 0.33 & \\
\hline 4 & 5 & 4 & 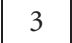 & 1 & 3 & 5 & & & & & 0.33 & 0.3 & & 0.3 & 0.2 & & \\
\hline A5 & 3 & 3 & 0.33 & 0 & 1 & 7 & 3 & & & 5 & & & 3 & 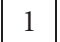 & 2 & & \\
\hline A6 & 0.5 & & 0. & 0 & 0.1 & 1 & 0. & & & & & & & & & & \\
\hline A7 & 0.3 & 0.33 & 0.2 & 0 & 0.3 & 3 & 1 & & A7 & 2 & 0.33 & 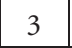 & 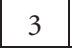 & 0.3 & 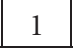 & 1 & \\
\hline \multicolumn{9}{|c|}{$\lambda \max =7.7679$, C.I $=0.127983$, C.R $=0.094802$} & \multicolumn{9}{|c|}{$\lambda \max =8.795$, C.I $=0.299167$, C.R $=0.221605$} \\
\hline \multicolumn{9}{|c|}{ D.1: Self-motivation } & \multicolumn{9}{|c|}{ D.2: Motivation from teachers } \\
\hline & A1 & A2 & A3 & A4 & A5 & A6 & A7 & $\mathrm{P}$ & & $\mathrm{A} 1$ & A2 & A3 & A4 & A5 & A6 & A7 & \\
\hline A1 & 1 & 0.1 & 1 & 0 & 0.1 & 0.1 & & & & & 0.12 & & 0.14 & 0.3 & 0.33 & & \\
\hline A2 & 9 & 1 & 1 & 0 & 0.2 & 0.2 & 0 & & A & r & . & - & 0.2 & 0.2 & 4 & 4 & \\
\hline A3 & 1 & 1 & 1 & 0 & 0.2 & 0.2 & 0.3 & & | & 0.2 & 0.2 & 1 & 0.11 & 0.3 & 0.2 & 3 & \\
\hline A4 & 9 & 5 & $J$ & 1 & 1 & 1 & 3 & & 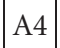 & 7 & - & 9 & 1 & 3 & 5 & 7 & \\
\hline 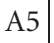 & 7 & 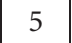 & 5 & 1 & 1 & 0.3 & 0.3 & & & 4 & 5 & 4 & 0.33 & 1 & 0.33 & 3 & \\
\hline A6 & 7 & 5 & 5 & 1 & 3 & 1 & 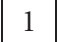 & & & 3 & 0.25 & 5 & 0.2 & 3 & 1 & 3 & \\
\hline A7 & 7 & 3 & 3 & 0 & 3 & 1 & 1 & & & 1 & 0.25 & 1 & 0.14 & 0.3 & 0.33 & 1 & 0.0334 \\
\hline \multicolumn{9}{|c|}{$\begin{array}{l}\lambda \max =7.7602, \text { C.I }=0.1267, \\
\text { C. } R=0.093852\end{array}$} & \multicolumn{9}{|c|}{$\begin{array}{l}\lambda \max =8.8593, \text { C.I }=0.309883 .09, \\
\text { C.R }=0.229543\end{array}$} \\
\hline
\end{tabular}


Table 5.9. Experts' opinions on alternatives with respect to different criteria.

\begin{tabular}{|c|c|c|c|c|c|c|c|c|c|c|c|c|c|c|c|c|c|}
\hline \multicolumn{9}{|c|}{ D.3: Motivation from parents } & \multicolumn{9}{|c|}{ E.1: Proper ventilation } \\
\hline & A1 & A2 & A3 & A4 & A5 & A6 & A7 & $\begin{array}{l}\text { Priority } \\
\text { vector }\end{array}$ & & $\mathrm{A} 1$ & A2 & A3 & A4 & A5 & A6 & A7 & \\
\hline $\mathrm{A} 1$ & 1 & 5 & & 5 & 7 & 3 & 0.3 & & & & 0.2 & 3 & 0.2 & 3 & 0.33 & 0.33 & 0.0893 \\
\hline 42 & 0.2 & 1 & & 5 & 7 & & & & & & & & & & f & & \\
\hline A3 & 7 & 5 & & 5 & 7 & & & & & 0.33 & 0.2 & & & 0.3 & 0.2 & & \\
\hline A4 & 0.2 & 0.2 & 0 & 1 & 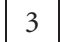 & 2 & & & & & 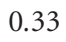 & & & & 3 & & \\
\hline A5 & 0.1 & 14 & & 0 & 1 & 2 & & & & 0.33 & 0 & & 2 & 1 & 0.2 & & \\
\hline A6 & 0.3 & 33 & 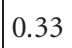 & 5 & 5 & & & & & & 4 & & J & 5 & & & \\
\hline A7 & 3 & 1 & 0.33 & 3 & 3 & 1 & 1 & & & $J$ & 0.5 & $J$ & 2 & 0.3 & 0.5 & 1 & \\
\hline \multicolumn{9}{|c|}{$\lambda \max =8.4067$, C.I $=0.23445$, C. $\mathrm{R}=0.173667$} & \multicolumn{9}{|c|}{$\lambda \max =8.7418$, C.I $=0.2903$, C.R $=0.215037$} \\
\hline \multicolumn{9}{|c|}{ E.2: Disturbances outside the room } & \multicolumn{9}{|c|}{$\begin{array}{l}\text { F.1: Difficulty in changing from } \\
\text { regional language to English }\end{array}$} \\
\hline & A1 & A2 & A3 & A4 & A5 & A6 & A7 & & & A1 & A2 & A3 & A4 & A5 & A6 & A7 & \\
\hline A1 & 1 & & & 0 & 3 & & & & & & 3 & & & & 3 & & \\
\hline A2 & 1 & 1 & 3 & 3 & 7 & & & & & & 1 & 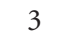 & 3 & & $J$ & & \\
\hline A3 & 3 & & 1 & 0 & 3 & 2 & & & & & 0.3 & & 0.2 & & 0.2 & & \\
\hline A4 & 5 & & 5 & 1 & 7 & 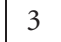 & & & & & & & & & 3 & & \\
\hline As & 0.3 & & & 0 & 1 & & & & & & & & & 1 & 0.25 & & \\
\hline A6 & 5 & 0. & 5 & 0 & 5 & 1 & & & 6 & 0.33 & 0.33 & & 0.33 & 4 & 1 & 0.5 & \\
\hline A7 & 3 & 0.2 & 3 & 3 & 3 & 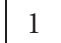 & 1 & & & & 3 & & 0.2 & 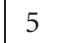 & 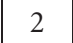 & & \\
\hline \multicolumn{9}{|c|}{$\lambda \max =7.9918$, C.I $=0.1653$, C. $R=0.122444$} & \multicolumn{9}{|c|}{$\lambda \max =8.6666, C . I=0.277767, C . R=0.205753$} \\
\hline \multicolumn{9}{|c|}{ F.2: Uneducated parents } & \multicolumn{9}{|c|}{ G.1: Influence of bad company } \\
\hline & A1 & A2 & A3 & A4 & A5 & A6 & A7 & & & A & A2 & A & A4 & A5 & A6 & A7 & \\
\hline A & 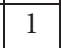 & 5 & & 7 & sta & & & & & & & & & & & & \\
\hline A2 & 0.2 & 1 & & 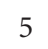 & s & 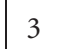 & & & & & 1 & 0.14 & 0.2 & $J$ & 0.33 & ( & \\
\hline A3 & 5 & 7 & 1 & 5 & 7 & 3 & & & & & 1 & & 5 & 7 & 3 & 14 & \\
\hline A4 & 0.1 & 0. & 0 & | & 3 & & & & & 0 & $J$ & & 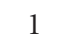 & 5 & 0.33 & 2 & \\
\hline A5 & 0.1 & & & 0 & 1 & 0.2 & 0. & & A5 & 0.14 & 0.2 & 0.14 & 0.2 & 1 & 0.14 & 0.2 & \\
\hline Ac & 0.3 & & & 3 & 5 & 1 & 1 & & & & 3 & & 3 & 7 & 1 & 0.14 & \\
\hline A7 & 0.3 & 0.33 & 0.33 & J & J & 1 & 1 & 0.057 & A7 & 0.33 & $\gamma$ & 7 & 5 & $J$ & 7 & 1 & 0.2992 \\
\hline
\end{tabular}
$\lambda \max =8.0249$, C.I $=0.170817$, C.R $=0.12631 \quad \lambda \max =8.795$, C.I $=0.299167$, C.R $=0.221605$

G.2: Effect of neighboring colleges and their schedules

G.3: Indiscipline

\begin{tabular}{c|c|c|c|c|c|c|c|c|c|c|c|c|c|c|c|c|c}
\hline & A1 & A2 & A3 & A4 & A5 & A6 & A7 & $\begin{array}{l}\text { Priority } \\
\text { vector }\end{array}$ & & A1 & A2 & A3 & A4 & A5 & A6 & A7 & $\begin{array}{l}\text { Priority } \\
\text { vector }\end{array}$ \\
\hline A1 & 1 & 0.33 & 4 & 0 & 5 & 0.5 & 0.2 & 0.024 & A1 & 1 & 5 & 1 & 3 & 5 & 3 & 0.33 & 0.1943 \\
A2 & 3 & 1 & 5 & 5 & 5 & 0.5 & 0.3 & 0.061 & A2 & 0.2 & 1 & 0.33 & 0.33 & 3 & 0.2 & 0.2 & 0.0449 \\
A3 & 0.3 & 0.2 & 1 & 0 & 3 & 0.2 & 0.2 & 0.045 & A3 & 1 & 3 & 1 & 0.33 & 5 & 0.33 & 0.33 & 0.0962 \\
A4 & 4 & 0.2 & 5 & 1 & 4 & 0.3 & 0.3 & 0.265 & A4 & 0.33 & 3 & 3 & 1 & 5 & 0.33 & 0.2 & 0.1047 \\
A5 & 0.2 & 0.2 & 0.33 & 0 & 1 & 0.3 & 0.3 & 0.159 & A5 & 0.2 & 0.33 & 0.2 & 0.2 & 1 & 0.2 & 0.14 & 0.0271 \\
A6 & 2 & 2 & 5 & 3 & 3 & 1 & 3 & 0.256 & A6 & 0.33 & 5 & 3 & 3 & 5 & 1 & 0.2 & 0.1544 \\
A7 & 5 & 3 & 5 & 4 & 3 & 0.3 & 1 & 0.189 & A7 & 3 & 5 & 3 & 5 & 7 & 5 & 1 & 0.3784 \\
\hline
\end{tabular}

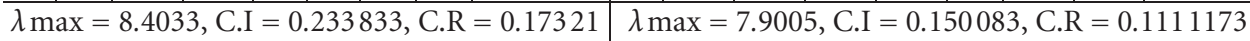


Table 5.10. Experts' opinions on alternatives with respect to different criteria.

\begin{tabular}{c|c|c|c|c|c|c|c|c|c|c|c|c|c|c|c|c|c}
\hline \multicolumn{10}{c}{ G.4: Lack of interest for engineering education } & \multicolumn{10}{c}{ H: Evaluation system } \\
\hline & A1 & A2 & A3 & A4 & A5 & A6 & A7 & $\begin{array}{l}\text { Priority } \\
\text { vector }\end{array}$ & & A1 & A2 & A3 & A4 & A5 & A6 & A7 & $\begin{array}{l}\text { Priority } \\
\text { vector }\end{array}$ \\
\hline A1 & 1 & 5 & 3 & 0 & 5 & 0.3 & 0.2 & 0.109 & A1 & 1 & 3 & 3 & 1 & 5 & 1 & 3 & 0.2522 \\
A2 & 0.2 & 1 & 5 & 0 & 3 & 0.3 & 0.2 & 0.064 & A2 & 0.33 & 1 & 3 & 3 & 0.3 & 5 & 5 & 0.1444 \\
A3 & 0.3 & 0.2 & 1 & 0 & 3 & 0.2 & 0.3 & 0.041 & A3 & 0.33 & 0.33 & 1 & 0.33 & 0.2 & 1 & 3 & 0.0752 \\
A4 & 3 & 5 & 7 & 1 & 7 & 3 & 0.3 & 0.26 & A4 & 1 & 0.33 & 3 & 1 & 0.3 & 3 & 5 & 0.1189 \\
A5 & 0.2 & 0.33 & 0.33 & 0 & 1 & 0.2 & 0.1 & 0.027 & A5 & 0.2 & 3 & 5 & 3 & 1 & 5 & 5 & 0.3209 \\
A6 & 3 & 3 & 5 & 0 & 5 & 1 & 0.3 & 0.16 & A6 & 1 & 0.2 & 1 & 0.33 & 0.2 & 1 & 0.33 & 0.0468 \\
A7 & 5 & 5 & 3 & 3 & 7 & 3 & 1 & 0.339 & A7 & 0.33 & 0.2 & 0.33 & 0.2 & 0.2 & 3 & 1 & 0.0415 \\
\hline
\end{tabular}

\begin{tabular}{l|l}
$\lambda \max =8.0354$, C.I $=0.172567$, C.R $=0.127827$ & $\lambda \max =8.7973$, C.I $=0.29955$, C.R $=0.221889$
\end{tabular}

\begin{tabular}{c|c|c|c|c|c|c|c|c|c|c|c|c|c|c|c|c|c}
\hline \multicolumn{1}{c|}{ I.1: Movies/drugs/other attractions } & \multicolumn{1}{c|}{ I.2: Communal/political activities } \\
\hline & A1 & A2 & A3 & A4 & A5 & A6 & A7 & $\begin{array}{l}\text { Priority } \\
\text { vector }\end{array}$ & & A1 & A2 & A3 & A4 & A5 & A6 & A7 & $\begin{array}{l}\text { Priority } \\
\text { vector }\end{array}$ \\
\hline A1 & 1 & 2 & 1 & 0 & 3 & 0.1 & 0.3 & 0.08 & A1 & 1 & 3 & 3 & 0.33 & 5 & 0.33 & 0.33 & 0.1264 \\
A2 & 0.5 & 1 & 0.33 & 0 & 5 & 0.3 & 0.3 & 0.056 & A2 & 0.33 & 1 & 0.33 & 0.2 & 5 & 0.2 & 0.33 & 0.0505 \\
A3 & 1 & 3 & 1 & 0 & 3 & 0.3 & 0.3 & 0.082 & A3 & 0.33 & 3 & 1 & 0.33 & 5 & 0.33 & 0.33 & 0.0857 \\
A4 & 5 & 3 & 3 & 1 & 7 & 3 & 0.5 & 0.26 & A4 & 3 & 5 & 3 & 1 & 7 & 3 & 0.33 & 0.2492 \\
A5 & 0.3 & 0.2 & 0.33 & 0 & 1 & 0.2 & 0.2 & 0.027 & A5 & 0.2 & 0.2 & 0.2 & 0.14 & 1 & 0.2 & 0.2 & 0.0263 \\
A6 & 7 & 3 & 3 & 0 & 5 & 1 & 0.3 & 0.176 & A6 & 3 & 5 & 3 & 0.33 & 5 & 1 & 1 & 0.203 \\
A7 & 3 & 3 & 3 & 2 & 5 & 3 & 1 & 0.316 & A7 & 3 & 3 & 3 & 3 & 5 & 1 & 1 & 0.2587 \\
\hline
\end{tabular}

$\lambda \max =7.7657$, C.I $=0.127617$, C.R $=0.094531 \quad \lambda \max =7.8499$, C.I $=0.14165$, C.R $=0.104926$

\begin{tabular}{c|c|c|c|c|c|c|c|c|c|c|c|c|c|c|c|c|c}
\hline \multicolumn{1}{c|}{ J: Lack of responsibility of student } & \multicolumn{1}{c}{ K: Irregular conduct of classes } \\
\hline & A1 & A2 & A3 & A4 & A5 & A6 & A7 & $\begin{array}{l}\text { Priority } \\
\text { vector }\end{array}$ & & A1 & A2 & A3 & A4 & A5 & A6 & A7 & $\begin{array}{l}\text { Priority } \\
\text { vector }\end{array}$ \\
\hline A1 & 1 & 0.11 & 0.33 & 0 & 3 & 0.2 & 0.3 & 0.262 & A1 & 1 & 0.14 & 0.33 & 1 & 0.3 & 1 & 0.33 & 0.0605 \\
A2 & 9 & 1 & 5 & 3 & 7 & 3 & 5 & 0.096 & A2 & 7 & 1 & 3 & 7 & 3 & 5 & 5 & 0.3945 \\
A3 & 3 & 0.2 & 1 & 0 & 3 & 0.2 & 0.3 & 0.243 & A3 & 3 & 0.33 & 1 & 3 & 3 & 5 & 3 & 0.2807 \\
A4 & 7 & 0.33 & 7 & 1 & 7 & 3 & 0.3 & 0.104 & A4 & 1 & 0.14 & 0.33 & 1 & 0.2 & 1 & 0.33 & 0.0392 \\
A5 & 0.3 & 0.14 & 0.33 & 0 & 1 & 0.2 & 0.3 & 0.024 & A5 & 3 & 0.33 & 0.33 & 5 & 1 & 0.33 & 0.33 & 0.0957 \\
A6 & 5 & 0.33 & 5 & 0 & 5 & 1 & 1 & 0.047 & A6 & 1 & 0.2 & 0.2 & 1 & 3 & 1 & 3 & 0.0562 \\
A7 & 3 & 0.2 & 3 & 3 & 3 & 1 & 1 & 0.224 & A7 & 3 & 0.2 & 0.33 & 3 & 3 & 0.33 & 1 & 0.0732 \\
\hline
\end{tabular}

$\lambda \max =8.0029$, C.I $=0.16715$, C.R $=0.123815 \quad \lambda \max =8.1506$, C.I $=0.191767$, C.R $=0.14205$

L: Participation in co curricular/extra curricular/cultural activities

M.1 : Preparation for GRE/TOEFL/GATE

\begin{tabular}{c|c|c|c|c|c|c|c|c|c|c|c|c|c|c|c|c|l}
\hline & A1 & A2 & A3 & A4 & A5 & A6 & A7 & $\begin{array}{l}\text { Priority } \\
\text { vector }\end{array}$ & & A1 & A2 & A3 & A4 & A5 & A6 & A7 & $\begin{array}{l}\text { Priority } \\
\text { vector }\end{array}$ \\
\hline A1 & 1 & 0.14 & 0.33 & 1 & 0.1 & 3 & 0.2 & 0.044 & A1 & 1 & 0.2 & 2 & 3 & 5 & 3 & 0.33 & 0.148 \\
A2 & 7 & 1 & 3 & 7 & 0.3 & 5 & 0.3 & 0.189 & A2 & 5 & 1 & 3 & 5 & 7 & 3 & 0.5 & 0.2846 \\
A3 & 3 & 0.33 & 1 & 3 & 0.2 & 3 & 1 & 0.11 & A3 & 0.5 & 0.33 & 1 & 3 & 5 & 0.33 & 0.2 & 0.0733 \\
A4 & 1 & 0.14 & 0.33 & 1 & 0.2 & 3 & 0.3 & 0.052 & A4 & 0.33 & 0.2 & 0.33 & 1 & 5 & 0.33 & 0.5 & 0.0575 \\
A5 & 9 & 3 & 5 & 5 & 1 & 9 & 3 & 0.41 & A5 & 0.2 & 0.14 & 0.2 & 0.2 & 1 & 0.33 & 0.2 & 0.026 \\
A6 & 0.3 & 0.2 & 0.33 & 0 & 0.1 & 1 & 0.3 & 0.048 & A6 & 0.33 & 0.33 & 3 & 3 & 3 & 1 & 1 & 0.1359 \\
A7 & 5 & 3 & 1 & 3 & 0.3 & 3 & 1 & 0.148 & A7 & 3 & 2 & 5 & 2 & 5 & 1 & 1 & 0.2747 \\
\hline
\end{tabular}

\begin{tabular}{ll|l}
\hline$\lambda \max$ & $=7.7204$, C.I $=0.120067$, C.R $=0.088939$ & $\lambda \max =8.0456$, C.I $=0.174267$, C. $R=0.129087$ \\
\hline
\end{tabular} 
Table 5.11. Experts' opinions on alternatives with respect to different criteria.

\begin{tabular}{l|c|c|c|c|c|c|c|c}
\hline \multicolumn{10}{c}{ M.2: Preparation for other courses } \\
\hline & A1 & A2 & A3 & A4 & A5 & A6 & A7 & $\begin{array}{c}\text { Priority } \\
\text { vector }\end{array}$ \\
\hline A1 & 1 & 0.33 & 2 & 0 & 7 & 0.3 & 0.5 & 0.121 \\
A2 & 3 & 1 & 5 & 2 & 5 & 0.5 & 0.5 & 0.124 \\
A3 & 0.5 & 0.2 & 1 & 0 & 0.2 & 0.3 & 0.1 & 0.075 \\
A4 & 3 & 0.5 & 3 & 1 & 3 & 0.3 & 0.5 & 0.102 \\
A5 & 0.1 & 0.2 & 5 & 0 & 1 & 0.3 & 0.3 & 0.042 \\
A6 & 3 & 2 & 3 & 3 & 3 & 1 & 1 & 0.147 \\
A7 & 2 & 2 & 7 & 2 & 3 & 1 & 1 & 0.388 \\
\hline
\end{tabular}

Table 5.12. Preferential weights.

\begin{tabular}{l|ccccc}
\hline Alternatives & Exp: 2 & Exp: 8 & Exp: 10 & Exp: 11 & GMM \\
\hline Counseling & 0.231966 & 0.143499 & 0.159546 & 0.146732 & 0.172335 \\
Infrastructure & 0.054596 & 0.115304 & 0.169058 & 0.195491 & 0.123878 \\
Involvement of parents & 0.221586 & 0.145902 & 0.208903 & 0.149565 & 0.183885 \\
Making lecture more attractive & 0.139387 & 0.097474 & 0.110956 & 0.156388 & 0.127811 \\
Curriculum revision/better evaluation & 0.111946 & 0.097962 & 0.09115 & 0.065676 & 0.092845 \\
Punishment/awards for attendance & 0.116242 & 0.208598 & 0.131552 & 0.120909 & 0.144547 \\
Peer pressure & 0.124277 & 0.191264 & 0.128835 & 0.165242 & 0.154702 \\
\hline
\end{tabular}

Table 5.13. Preferential ranks.

\begin{tabular}{l|ccccc}
\hline Alternatives & Exp: 2 & Exp: 8 & Exp: 10 & Exp: 11 & GMM \\
\hline Counseling & 1 & 4 & 3 & 5 & 2 \\
Infrastructure & 7 & 5 & 2 & 1 & 6 \\
Involvement of parents & 2 & 3 & 1 & 4 & 1 \\
Making lecture more attractive & 3 & 7 & 6 & 3 & 5 \\
Curriculum revision/better evaluation & 6 & 6 & 7 & 7 & 7 \\
Punishment/awards for attendance & 5 & 1 & 4 & 6 & 4 \\
Peer pressure & 4 & 2 & 5 & 2 & 3 \\
\hline
\end{tabular}

The group preferential weights of alternative solutions are shown in Figure 5.1. It is clear from Figure 5.1 that, involvement of parents is given first preference, counseling the second preference, peer pressure the third preference, punishment/awards for attendance the fourth preference, making lecture more attractive the next preference, infrastructure the next preference, and curriculum revision/better evaluation is the least preferred. 


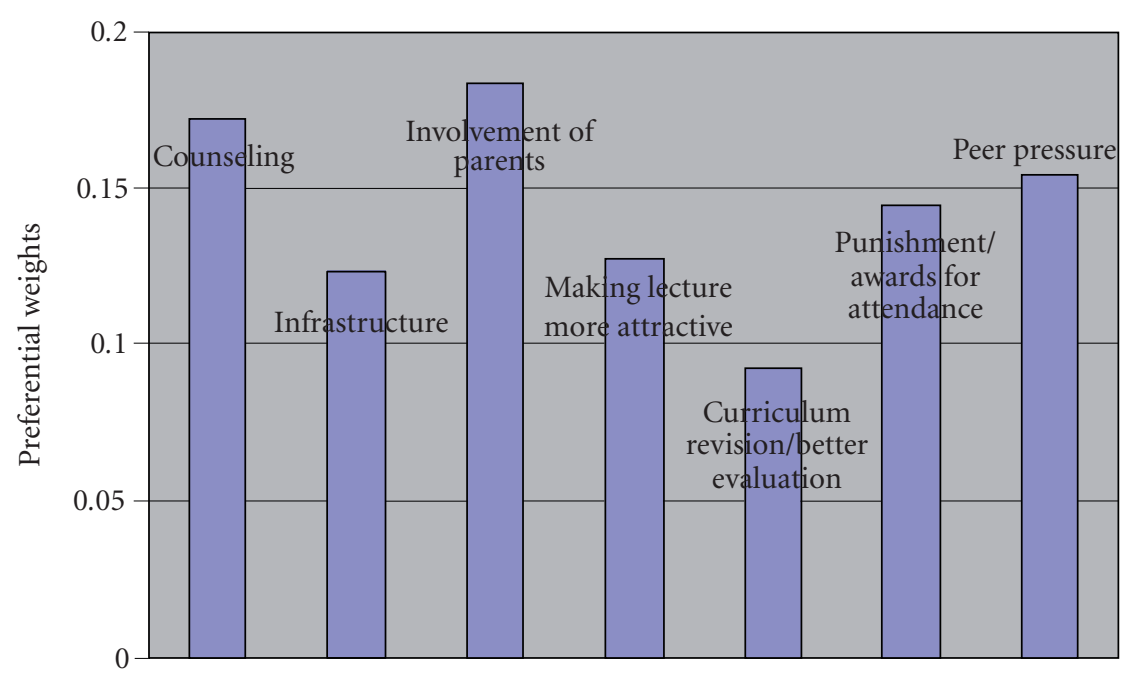

Alternative solutions

GMM

Figure 5.1. Group preferential weights of alternative solutions.

\section{Summary, results, and discussion}

The utility of multicriteria decision-making methods is presented in this paper. By conducting Delphi study, data from the preliminary round questionnaire survey from experts, and criteria, which influence student absenteeism, were identified and the hierarchy of the criteria/subcriteria was formed. Next, from the first round questionnaire survey, the importance weights of the criteria influencing student absenteeism were calculated. Appropriateness weights of alternatives are found using Eigenvector method given in Section 5.2. Composite weights are found by multiplying appropriateness weights of alternatives under each criterion with its global importance weight. Then preferential weights are found by adding all composite weights of that alternative.

The results from Tables 5.12 and 5.13 show that the order of preferences slightly changes for different experts. Out of the four experts, Exp: 10 prefers involvement of parents as the best alternative which is the same as the group preference (GMM) of experts. Exp: 2 prefers counseling, Exp: 8 prefers punishment/awards for attendance, and Exp: 11 prefers infrastructure as the best alternative. When counseling is the second best alternative of GMM and Exp: 2 prefers involvement of parents, Exp: 8 and Exp: 11 prefer peer pressure, and Exp: 10 prefers infrastructure as second best alternative. Next, making lecture more attractive is preferred as the next best alternative by two experts (Exp: 2 and Exp: 11). Exp: 10 prefers counseling and Exp: 8 prefers Involvement of parents as the next best alternative. Curriculum revision/better evaluation is less preferred by Exp: 2 and Exp: 8, making lecture more attractive is less preferred by Exp: 10, whereas punishment/awards for attendance is 
less preferred by Exp: 11. Curriculum revision/better evaluation is least preferred by Exp: 10 and Exp: 11, which is the same as that of group preferences. Exp: 2 prefers infrastructure as the least preferred alternative and Exp: 8 prefers making lecture more attractive the least.

Many criteria like frequent ill health, monetary problems, motivation from parents, uneducated parents, influence of bad company, lack of interest for engineering education, movies/drugs/other attractions, communal/political activities can be reduced or curbed by the alternative solution involvements of parents to know their wards' day-today progress. This may be reason for giving greater preference to this alternative by the experts. Teachers and parents are to be involved in making the student/ward regular to the college and befit to engineering education. This can be done by regular counseling of the student. This may be the reason for preferring counseling as the second best alternative by the experts.

The case discussed in this paper is for engineering colleges of Andhra Pradesh. However to apply this model to other states or countries or to any other location, the following steps could be followed.

(i) Experts' opinions on relative importance of criteria shown in Figure 4.1, for that location has to be collected using the scale shown in Table 4.1.

(ii) For each of these last level criteria/subcriteria, data on alternatives has to be collected.

(iii) By inputting the above data, the priorities of alternative solutions for that location can be found, using the software developed by the authors.

\subsection{Scope for further study and limitations of the study.}

6.1.1. Scope. Research works on various aspects of AHP, in general, should be carried on. Few of the worth-pursuing directions are mentioned below.

Sensitivity analysis can be performed on expert weights, criteria priorities, and ratings on the results to see if the rankings change.

Since the nature of the problem of reducing student absenteeism in engineering colleges involves social, economic, and cultural factors, non-availability of exact data, and solutions applied by experts that may be subjective by nature, fuzzy hierarchical decisionmaking method can be applied to this problem and refine the solution by synthesizing the concepts of multicriteria decision-making method and fuzzy analysis.

The study mainly used a questionnaire for getting the importance criteria and priorities of alternatives. Hence, the accuracy and exactness of the data/information collected may not be cent percent. Therefore, inaccuracies crept in, on account of communication problems, though every care was taken to lessen them. Though the analysis reflects the situations that prevail during 2005-2006, this may be applicable for quite a long period.

6.1.2. Limitations. The major limitation of the study is that the number of respondents for ranking of the criteria/subcriteria is only five, and for the final alternatives, the number of respondents is only four. Even though the number of respondents differs in their ranking criteria/subcriteria, all the five experts have ranked the same criteria as first nine criteria. 
Though, in such a study, no minimum number is fixed, we feel that a sample of 15-20 would have been better like in Delphi study. Many of the panelists expressed that there are too many cells to be filled and it takes a very long time, which they cannot spare. However, the respondents are highly experienced (number of years of experience, resp., are 32, 26, 22, and 17) in engineering education. Therefore, the study result can be taken into serious consideration. The practitioners can always develop their own values for the cells in order to determine the rankings in their environment.

As this paper is only an application of existing method, a better mechanism to consolidate disparate expert opinions could not be provided. However, sensitivity analysis could be performed on fuzzy decision-making, which is beyond the scope of the present paper.

\section{References}

[1] S. A. Boloz and D. C. Lincoln, Combating student absenteeism: strategies for raising attendance and achievement, Journal of American Indian Education 22 (1983), no. 3, 25-30.

[2] C. Day, B. Elliot, and A. Kington, Reform, standards and teacher identity: challenges of sustaining commitment, Teaching and Teacher Education 21 (2005), no. 5, 563-577.

[3] Department of Education, Chronic Student absenteeism 2002-2003, Florida Information Notes, March issue, Series 2004-13F (2004).

[4] Director of Health Services, Student Absenteeism Due to Illness or Injury, University of Pittsburgh, Pennsylvania, 2005.

[5] J. S. Dyer, A clarification of "remarks on the analytic hierarchy process", Management Science 36 (1990), no. 3, 274-275.

[6] __ Remarks on the analytic hierarchy process, Management Science 36 (1990), no. 3, 249275.

[7] T. Garvin, Politics department blames student absenteeism for high failure rates, Observer 11 (2004), no. 4.

[8] A. H. Gorman, J. Kim, and A. Schimmelbusch, The attributes adolescents associate with peer popularity and teacher preference, Journal of School Psychology 40 (2002), no. 2, 143-165.

[9] P. T. Harker, The art of science and decision-making: the analytic hierarchy process, The Analytic Hierarchy Process: Applications and Studies, vol. 79, Springer, New York, 1989, pp. 3-36.

[10] P. T. Harker and L. G. Vargas, Reply to "remarks on the analytic hierarchy process" by J. S. Dyer, Management Science 36 (1990), no. 3, 269-273.

[11] R. Islam, On some aspects of the analytic hierarchy process, Doctoral thesis, IIT, Kharagpur, 1995.

[12] P. Kousalya, Student absenteeism in engineering colleges: a survey, Working Report, Vignan Institute of Technology and Science, Andhra Pradesh, 2004.

[13] National Center for Educational Statistics, Principals' Perceptions of Discipline Issues in Their Schools, Fast Response Survey System, 1998, http://nces.ed.gov/surveys/frss/publications/ 98030/4.asp.

[14] J. Pearce, An analysis of student absenteeism in first year biology students, Project Report, Center for Bioscience, The Higher Education Academy, Leeds, 2004.

[15] G. E. Philips-Wren, E. D. Hahn, and G. A. Forgionne, A multiple-criteria framework for evaluation of decision support systems, Omega 32 (2004), no. 4, 323-332.

[16] T. R. Prabhu, Technology choice: methodology and a case study, Doctoral thesis, IIT, Kharagpur, 1997.

[17] T. R. Prabhu and K. VizayaKumar, Fuzzy hierarchical decision making (FHDM): a methodology for technology choice, International Journal of Computer Applications in Technology 9 (1996), no. 5-6. 
[18] _ Technology choice using FHDM: a case of iron-making technology, IEEE Transactions on Engineering Management 48 (2001), no. 2, 209-222.

[19] R. Ramanathan and L. S. Ganesh, Group preference aggregation methods employed in AHP: an evaluation and an intrinsic process for deriving members' weightages, European Journal of Operational Research 79 (1994), no. 2, 249-265.

[20] K. B. Reddy, N. H. Ayachit, and M. K. Venkatesha, A theoretical method for performance evaluation of technical institutions-analytic hierarchy process approach, The Indian Journal of Technical Education 25 (2004), no. 1, 19-25.

[21] T. L. Saaty, Exploring the interface between hierarchies, multiple objectives and fuzzy sets, Fuzzy Sets and Systems 1 (1978), no. 1, 57-68.

[22] _ The Analytic Hierarchy Process, McGraw-Hill, New York, 1980.

[23] _ An exposition of the AHP in reply to the paper "remarks on the analytical hierarchy process", Management Science 36 (1990), no. 3, 259-268.

[24] How to make a decision: the analytic hierarchy process, European Journal of Operational Research 48 (1990), no. 1, 9-26.

[25] S. Silverstein, Computer Classes Spur Student Absenteeism, Los Angeles Times, January 2006.

[26] F. Timmins and M. Kaliszer, Attitudes to absenteeism among diploma nursing students in Ireland - an exploratory descriptive survey, Nurse Education Today 22 (2002), no. 7, 578-588.

[27] J. Yue, B. Chen, and M.-C. Wang, Generating ranking groups in the analytical hierarchy process, Journal of the Operational Research Society 57 (2006), no. 2, 190-201.

[28] Office of Educational Research and Improvement Survey on disciplinary issues among students, U.S. Department of Education (1997).

P. Kousalya: Center for Mathematical Sciences, Vignan Institute of Technology \& Science, Vignan Hills, Deshmukhi, Nalgonda 508 284, Andhra Pradesh, India

E-mail address: kousalya29@yahoo.com

V. Ravindranath: Department of Mathematics, College of Engineering, Jawaharlal Nehru Technological University, Kakinada 533 003, Andhra Pradesh, India

E-mail address: nath_vr@yahoo.com

K. VizayaKumar: Department of Industrial Engineering \& Management, Indian Institute of Technology, Kharagpur 721302, India

E-mail addresses: vizay@hijli.iitkgp.ernet.in; vizaya@gmail.com 


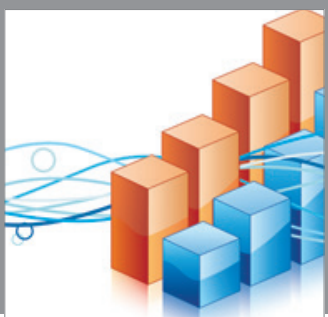

Advances in

Operations Research

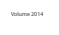

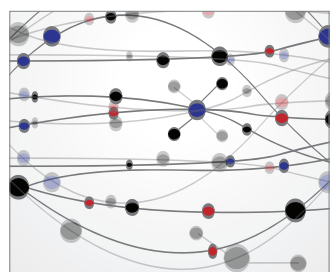

\section{The Scientific} World Journal
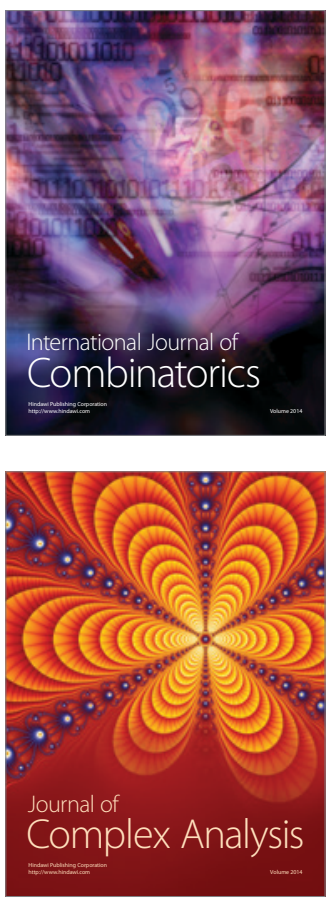

International Journal of

Mathematics and

Mathematical

Sciences
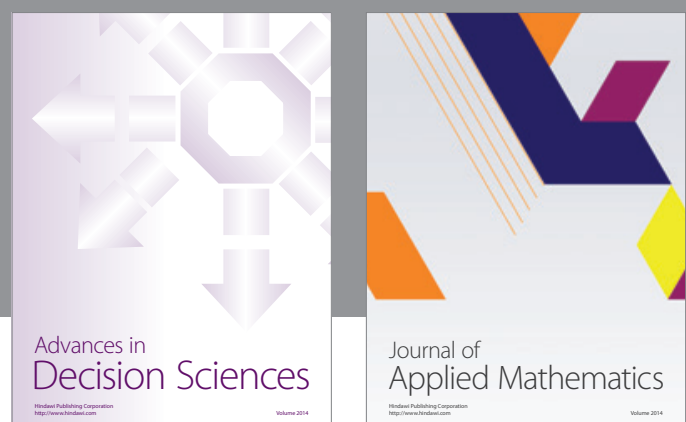

Journal of

Applied Mathematics
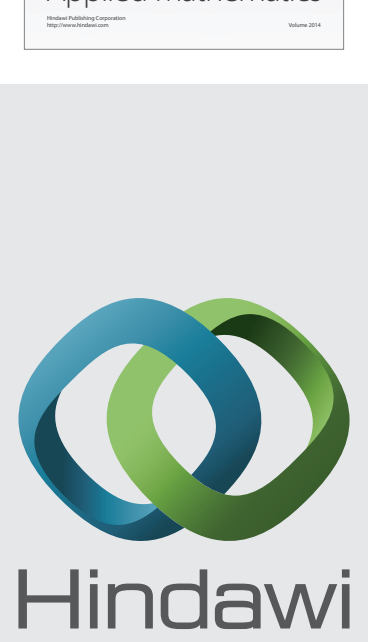

Submit your manuscripts at http://www.hindawi.com
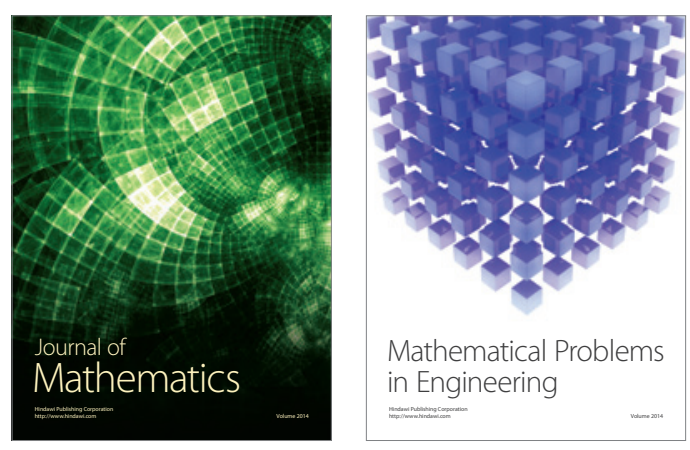

Mathematical Problems in Engineering
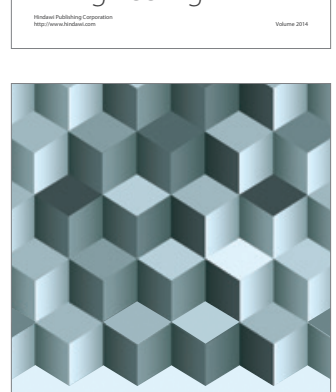

Journal of

Function Spaces
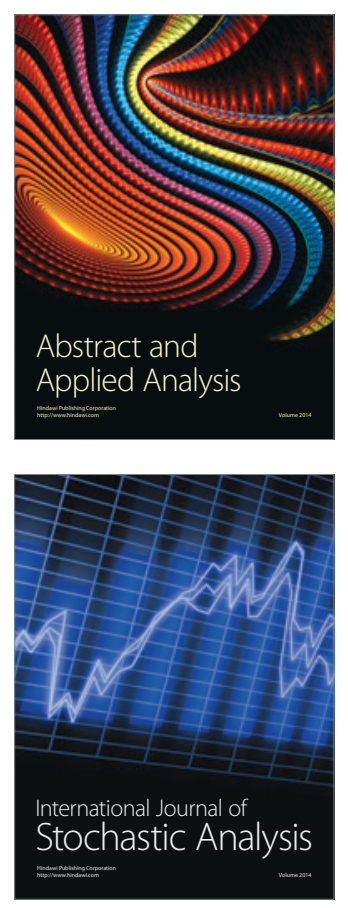

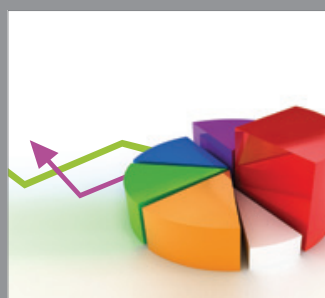

ournal of

Probability and Statistics

Promensencen
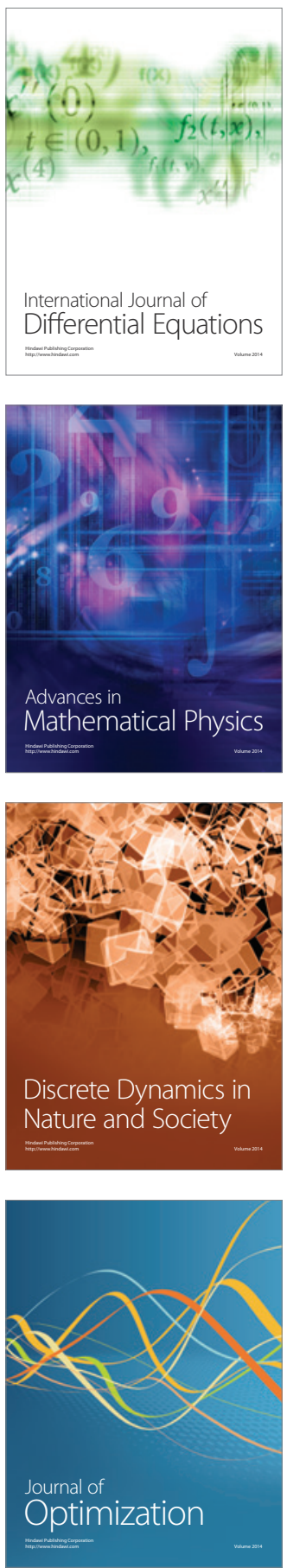